\title{
Vasculitis of the Gastrointestinal Tract in Chronic Periaortitis
}

\author{
Carlo Salvarani, MD, Kenneth T. Calamia, MD, Eric L. Matteson, MD, MPH, Gene G. Hunder, MD, \\ Nicolò Pipitone, MD, PhD, Dylan V. Miller, MD, and Kenneth J. Warrington, MD
}

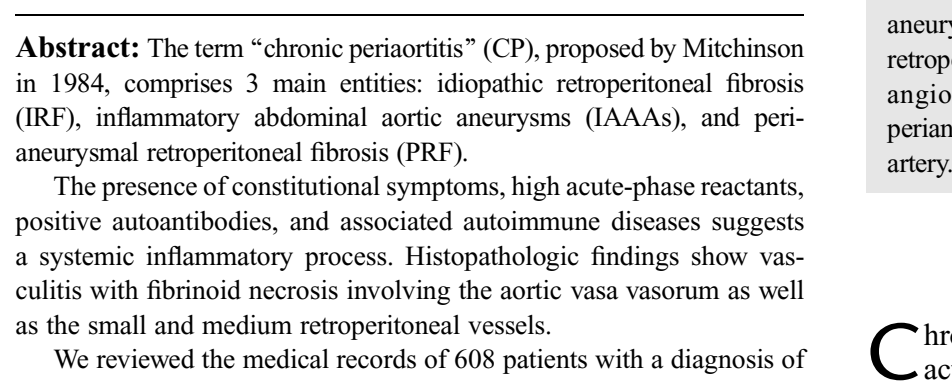

aneurysm, IMA = inferior mesenteric artery, IRF = idiopathic retroperitoneal fibrosis, $\mathrm{IV}=$ intravenous, $\mathrm{MRA}=$ magnetic resonance angiography, $\mathrm{MRI}=$ magnetic resonance imaging, $\mathrm{PRF}=$ perianeurysmal retroperitoneal fibrosis, SMA $=$ superior mesenteric

\section{INTRODUCTION} vasculitis involving the gastrointestinal (GI) tract at the Mayo Clinic between January 1996 and December 2007. Only patients with biopsyproven or typical angiographic findings of vasculitis localized to the GI tract were included.

Five patients were identified with evidence of CP (1 patient with PRF, 1 with IRF, and 3 with IAAAs). Three patients were men, and the median age at diagnosis was 49 years. The diagnosis of GI vasculitis and CP was made simultaneously in 4 patients. At the time of onset, all patients had abdominal pain and constitutional manifestations; the median erythrocyte sedimentation rate was $62.5 \mathrm{~mm} / 1 \mathrm{~h}$ (range, $20-86 \mathrm{~mm} / 1 \mathrm{~h}$ ). All patients had evidence of mesenteric vasculitis at angiography. Three patients also had associated renal artery stenoses. Abdominal computed tomography showed spleen infarcts in 2 patients, bowel wall thickening in 1, and liver infarction in 1. Two patients underwent surgical intervention for acute abdomen; there was histologic evidence of small bowel infarcts and infarction of the spleen and liver in 1. Oral prednisone was administered to all 5 patients (median starting dose, $60 \mathrm{mg} / \mathrm{d}$; range, $25-80 \mathrm{mg} / \mathrm{d}$ ). Three patients also received immunosuppressive agents, 1 tamoxifen, and 1 anti-tumor necrosis factor therapy. All patients had at least 1 relapse or recurrence of vasculitis, but at last visit, GI vasculitis and CP were in remission in all 5 patients.

This study provides evidence that GI manifestations due to mesenteric vasculitis may be associated with CP. Vasculitic involvement of the renal arteries is also frequently present in these patients. Aggressive immunosuppressive treatment should be promptly initiated to forestall abdominal complications. These findings reinforce the hypothesis that a vasculitic process plays an important role in the pathogenesis of $\mathrm{CP}$.

(Medicine 2011;90: 28-39)

Abbreviations: $\mathrm{ANCA}=$ antineutrophil cytoplasmic antibody, $\mathrm{CP}=$ chronic periaortitis, $\mathrm{CRP}=\mathrm{C}$-reactive protein, $\mathrm{CT}=$ computerized tomography, ENA = extractable nuclear antigens, ESR = erythrocyte sedimentation rate, FDG-PET $=18 \mathrm{~F}$-fluorodeoxyglucose-positron emission tomography, GI = gastrointestinal, HIV = human immunodeficiency virus, IAAA = inflammatory abdominal aortic

From Unità di Reumatologia (CS, NP), Arcispedale S. Maria Nuova, Reggio Emilia, Italy; Division of Rheumatology (KTC), Mayo Clinic, Jacksonville, Florida; Division of Rheumatology (ELM, GGH, KJW), and Division of Anatomic Pathology (DVM), Mayo Clinic, Rochester, Minnesota.

Reprints: Dr. Carlo Salvarani, MD, Servizio di Reumatologia,

Arcispedale S. Maria Nuova, V. le Risorgimento N80, 42100 Reggio

Emilia, Italy (e-mail: salvarani.carlo@asmn.re.it).

Copyright $(\subset 2011$ by Lippincott Williams \& Wilkins

ISSN: 0025-7974

DOI: 10.1097/MD.0b013e318207231e hronic periaortitis (CP) is a clinical pathologic entity characterized by a fibroinflammatory reaction that extends from the adventitia of the abdominal aorta and the common iliac arteries into the retroperitoneum, and often leads to the encasement of adjacent structures (ureters, inferior vena cava). ${ }^{31,35,43}$ $\mathrm{CP}$ may be viewed as comprising 3 main entities: idiopathic retroperitoneal fibrosis (IRF), inflammatory abdominal aortic aneurysms (IAAAs), and perianeurysmal retroperitoneal fibrosis (PRF). These conditions have common clinical and histopathologic findings, and thus probably represent different manifestations of the same disease.

Although CP has traditionally been considered an exuberant local inflammatory response to atherosclerotic plaque antigens, its clinical presentation is characterized by constitutional symptoms and elevated inflammatory markers, which suggests a systemic inflammatory process as the underlying pathogenesis disease mechanism. ${ }^{35-37,45}$

Histopathologic findings typically reveal vasculitis with fibrinoid necrosis involving the aortic vasa vasorum as well as the small and medium-sized retroperitoneal vessels in most patients. ${ }^{11,26,31,44,46} 18 \mathrm{~F}$-fluorodeoxyglucose-positron emission tomography (FDG-PET) studies in patients with $\mathrm{CP}$ have demonstrated large-vessel vasculitis involving the abdominal aorta and the common iliac arteries. In some patients, vasculitis also involved the thoracic aorta and/or its main branches. ${ }^{40}$ Furthermore, an association between $\mathrm{CP}$ and granulomatous necrotizing (antineutrophil cytoplasmic antibody [ANCA]-associated) vasculitis, polyarteritis nodosa, and Henoch-Schönlein purpura has been described in some patients. ${ }^{1-7,9,10,12,14,15,17,18,22,24,28-30,41,42,48}$ These findings raise the question of whether CP should be regarded as a form of idiopathic vasculitis.

As part of a recent review of 608 consecutive patients with vasculitis of the gastrointestinal (GI) tract seen at the Mayo Clinic (Rochester, MN) over 12 years, ${ }^{39}$ we identified 5 patients with evidence of $\mathrm{CP}$ at the time of the onset of GI symptoms. In the current report, we describe the clinical, laboratory, radiology, and pathology findings, as well as the treatment and outcome of these 5 patients. In addition, we review the relevant literature regarding the association between $\mathrm{CP}$ and established vasculitides.

\section{PATIENTS AND METHODS}

\section{Identification of Patients}

We conducted a retrospective medical record review of all patients seen at the Mayo Clinic from January 1, 1996, through December 31,2007, who had a diagnosis of vasculitis involving 
the GI tract. Using the institution's medical diagnostic linkage system, we screened the electronic medical records for a diagnosis of vasculitis in combination with key indexing terms. These terms included the following: mesenteric arteries, celiac artery, gastric artery, hepatic artery, splenic artery, esophagus, stomach, small intestine, jejunum, ileum, appendix, colon, rectum, gallbladder, pancreas, liver, and spleen. We reviewed the records of all identified patients with findings of vasculitis involving the GI tract and IRF, IAAA, and PRF. ${ }^{39}$ The study was approved by the Mayo Clinic Institutional Review Board.

\section{Diagnostic Criteria}

The presence of GI vasculitis was ascertained using the following criteria:

1) recent history or presence of acquired GI manifestations;

2) histopathologic evidence of vasculitis in a GI specimen; and/or

3) high-probability angiographic findings (smooth segmental narrowing, dilatation, occlusion, or aneurysms affecting 1 or more GI arteries in the absence of vessel changes suggestive of atherosclerosis or of vasculitis mimics such as fibromuscular dysplasia) with a report by the Mayo Clinic radiologist specifically stating that the angiographic findings were consistent with vasculitis.

Retroperitoneal fibrosis and IAAA were diagnosed by computerized tomography (CT) and magnetic resonance imaging
(MRI). IAAAs were identified by the presence of aortic wall thickening and the presence of an inflammatory soft tissue cuff around the aneurysm.

\section{Data Collection}

The clinical records, radiologic images, pathologic specimens, and autopsy data were used to abstract detailed data, including CT and MRI, angiographic data, and results of biopsies. Available pathologic specimens were reviewed. In addition, information on treatment regimens, response to treatment, presence and number of relapses, follow-up functional status, and cause of death if relevant was retrieved from the clinical record whenever available. Response to therapy was based on documentation by the treating physician. Relapses were defined as an increase in or progression of disease activity requiring more aggressive therapy.

\section{Review of the Literature}

We searched the PubMed database (National Library of Medicine, Bethesda, MD) using the keywords "retroperitoneal fibrosis," "chronic periaortitis," "periaortitis," "Takayasu arteritis," "giant cell arteritis," "polyarteritis nodosa," "Wegener's granulomatosis," "microscopic polyangiitis," "Churg-Strauss syndrome," "Henoch-Schönlein purpura," "cryoglobulinemic vasculitis," "leukocytoclastic angiitis," and "glomerulonephritis" to retrieve relevant clinical reports of the conditions of interest.
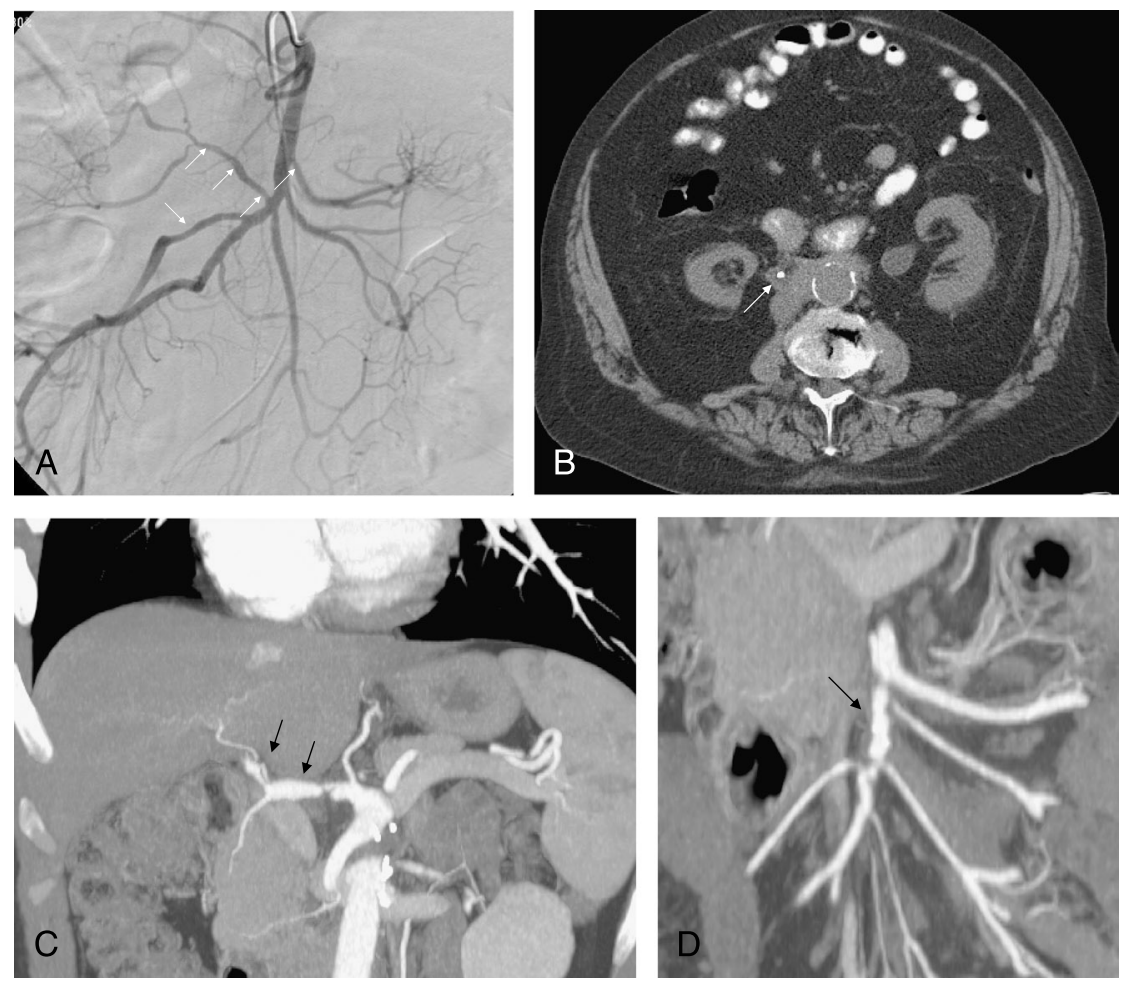

FIGURE 1. A, Mesenteric angiogram: there are numerous areas of luminal irregularity in multiple visceral branches of the superior mesenteric artery (arrows). Areas of smooth narrowing, as well as slight dilatation are seen. B, CT of the abdomen: retroperitoneal fibrosis around the aorta and proximal right ureter (ureteral stent present, arrow). C, Abdominal CT angiogram: beginning in the common hepatic and extending into the hepatic artery, the artery is dilated and irregular with areas of stenosis (arrows). D, Abdominal CT angiogram: the SMA is irregular with a thickened wall and areas of stenosis (arrow), including stenoses involving the origins of the jejunal and ilial branches. 


\section{CASE REPORTS}

\section{Case 1}

A 77-year-old man presented with deep vein thrombosis of the left lower extremity, following which he was anticoagulated. Four months later, he noted the onset of malaise, fever, fatigue, and anorexia. Over the next 3 months, he developed progressive abdominal pain, further appetite loss, diarrhea, and weight loss of $13 \mathrm{~kg}$ in 4 months, and was hospitalized. Upper endoscopy showed moderately severe reflux esophagitis and hiatal hernia. Colonoscopy showed a segmental area of ischemic colitis. Contrast-enhanced CT of the abdomen and pelvis revealed soft tissue thickening partially surrounding the thickened infrarenal abdominal aorta and circumferentially thickened inferior mesenteric artery (IMA) consistent with retroperitoneal fibrosis. A visceral angiogram showed abnormalities in the superior mesenteric artery (SMA) distribution with numerous areas of luminal irregularity (areas of smooth narrowing, as well as slight dilatation) in multiple visceral branches consistent with GI vasculitis (Figure 1A). CT of the chest was unremarkable. Left temporal artery biopsy was negative for arteritis. Hepatitis B and C serologies, ANCA, cryoglobulins, antinuclear, anti-DS-DNA and anti-extractable nuclear antigens (ENA) antibodies were negative. Erythrocyte sedimentation rate (ESR) was $86 \mathrm{~mm} / 1 \mathrm{~h}, \mathrm{C}$-reactive protein (CRP) was $15 \mathrm{mg} / \mathrm{dL}$ (normal to $8 \mathrm{mg} / \mathrm{dL}$ ), and hemoglobin was $8.9 \mathrm{gm} / \mathrm{dL}$.

Based on these findings, diagnosis of GI tract vasculitis was made and treatment with prednisone $80 \mathrm{mg} / \mathrm{d}$ commenced. Two weeks later, the patient was feeling significantly better and had no fever and no abdominal cramping. Appetite, fatigue, and overall well-being were markedly improved. ESR and CRP were normal $(8 \mathrm{~mm} / 1 \mathrm{~h}$ and $<0.3 \mathrm{mg} / \mathrm{dL}$, respectively), and hemoglobin was $12.8 \mathrm{~g} / \mathrm{dL}$. The prednisone dose was tapered to $10 \mathrm{mg}$ by 7 months following diagnosis with continued clinical remission. ESR and CRP were $17 \mathrm{~mm} / 1 \mathrm{~h}$ and $1.02 \mathrm{mg} / \mathrm{dL}$, respectively. The prednisone dose was further tapered, albeit very slowly because of the persistence of slightly elevated CRP values.

Twenty-one months later, the prednisone dose was $4 \mathrm{mg} / \mathrm{d}$. Six months later, the patient developed bilateral hydrocele, creatinine increased to $1.8 \mathrm{mg} / \mathrm{dL}$, and ESR and CRP to $35 \mathrm{~mm} / 1 \mathrm{~h}$ and $8.4 \mathrm{mg} / \mathrm{dL}$, respectively. The patient was still asymptomatic; however, MRI/MR angiography (MRA) of the chest and abdomen showed an area of aneurysmal ectasia of the infrarenal abdominal aorta and bilateral renal artery stenoses. There was a considerable amount of abnormal soft tissue enveloping the retroperitoneal vascular structures from just below the level of the renal arteries and extending inferiorly along the most proximal aspect of the right common iliac vessels. This soft tissue also extended to the aortocaval space and encircled the inferior vena cava at and below the level of the left renal vein, resulting in extrinsic compression and narrowing of the inferior vena cava in this region. There was compression of the upper right ureter with moderate pyelocalyectasis, which had developed from the prior CT. CT-guided biopsy of the paracaval retroperitoneal soft tissue was performed, which revealed changes consistent with retroperitoneal fibrosis (Figure 2A).

The patient remained asymptomatic, while the prednisone dose was kept at $4 \mathrm{mg} / \mathrm{d}$. However, 3 months later retroperitoneal ultrasonography showed right hydro-ureteronephrosis. A right ureteral stent was placed (Figure 1B), prednisone was increased to $30 \mathrm{mg} / \mathrm{d}$, and tamoxifen $20 \mathrm{mg} / \mathrm{d}$ was started. The prednisone dose was subsequently gradually reduced, and the stent was periodically changed. The patient remained clinically asymp-
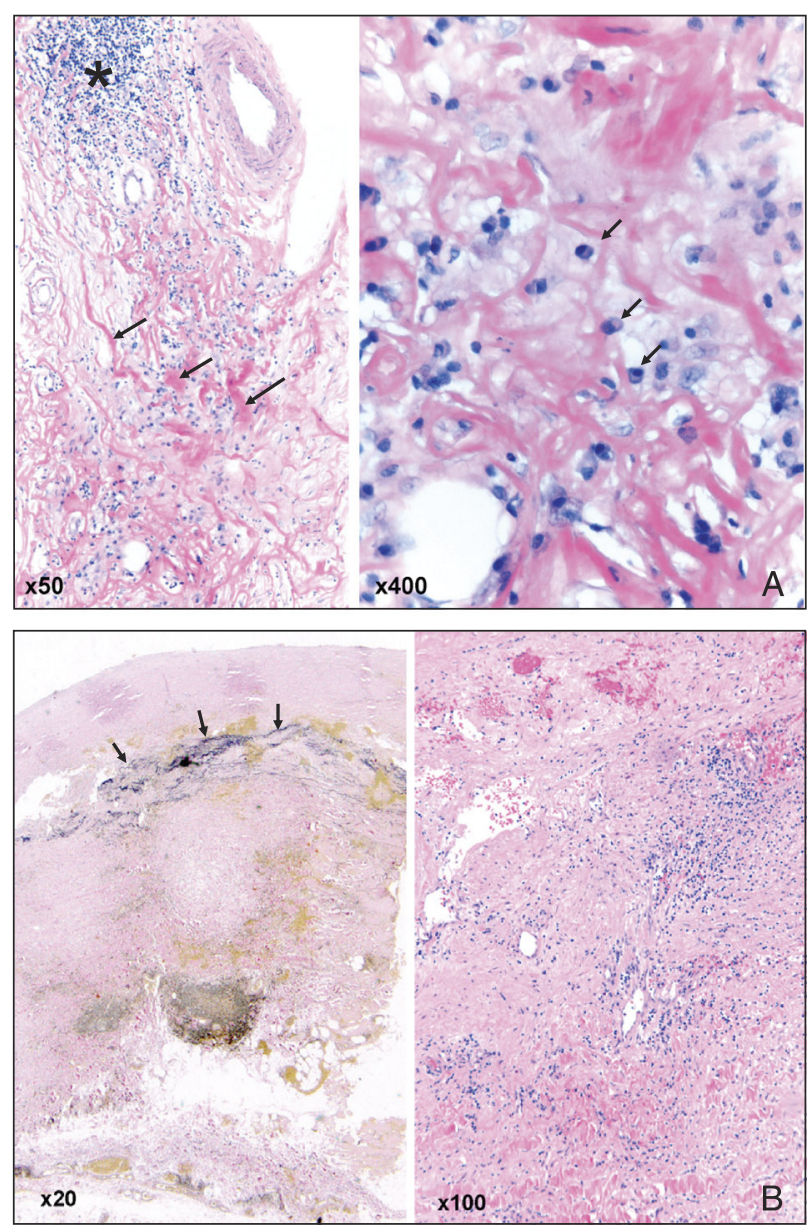

FIGURE 2. A, Photomicrographs of a core biopsy specimen showing typical features of retroperitoneal fibrosis including dense collagenous fibrosis (arrows, left panel) and chronic inflammation (asterisk). Plasma cells are a prominent component of the inflammatory infiltrate (arrows, right panel) (hematoxylin and eosin stain). B, Photomicrographs from an abdominal aortic aneurysm wall specimen showing a thinned medial layer (black-staining elastic fibers, arrows, left panel) with marked peri-adventitial fibrosis and chronic inflammation. Lymphocytes were more prominent than plasma cells. IgG4 staining was performed and showed no increase in IgG4 plasma cells (left: Verhoeff-van Gieson elastic stain, right: hematoxylin and eosin stain).

tomatic, while the extension of retroperitoneal soft tissue and the size of the aneurysm remained unchanged on the several subsequent CT scans of the abdomen and pelvis.

Three years later therapy consisted of prednisone $5 \mathrm{mg} / \mathrm{d}$ and tamoxifen $20 \mathrm{mg} / \mathrm{d}$. At this follow-up, there was still evidence of bilateral hydroceles, but the right one had become more tense and fuller. There was a modest increase in CRP and ESR ( $3.3 \mathrm{mg} / \mathrm{dL}$ and $35 \mathrm{~mm} / 1 \mathrm{~h}$, respectively), and some concern that fibrosis on CT might be worse. Therefore, the prednisone was increased to $10 \mathrm{mg} / \mathrm{d}$ and methotrexate, $15 \mathrm{mg} / \mathrm{wk}$ substituted for the tamoxifen. At the most recent follow-up visit 3 months later, there had been no recurrence of symptoms attributable to GI vasculitis or retroperitoneal fibrosis, and ESR and CRP were $5 \mathrm{~mm} / 1 \mathrm{~h}$ and $0.4 \mathrm{mg} / \mathrm{dL}$, respectively. 


\section{Case 2}

A 63-year-old man was seen for a second opinion regarding a previous diagnosis of possible vasculitis dating back 25 years. At that time, he had developed a systemic inflammatory illness with fever, night sweats, fatigue, generalized aching, and loss of appetite with nausea and abdominal pain. He underwent an extensive evaluation including muscle biopsy, temporal artery biopsy, and mesenteric angiogram, which were all unrevealing. He was started empirically on prednisone $60 \mathrm{mg} /$ $\mathrm{d}$ with complete resolution of symptoms. Since that time prednisone had been continued, generally at a dose of $10 \mathrm{mg} / \mathrm{d}$, with few interruptions. Over all these years, there had been no clear evidence of major organ involvement.

At the time of initial evaluation at the Mayo Clinic, the patient was taking prednisone $10 \mathrm{mg} / \mathrm{d}$ and had no clear-cut symptoms suggestive of an underlying systemic vasculitis or connective tissue disease. Mild renal insufficiency was noted (creatinine, $1.6 \mathrm{mg} / \mathrm{dL}$ ). Physical examination revealed only degenerative changes of the hands.

Investigations at that point included MRA of the chest vessels, which was negative. MRA of the abdomen showed stenosis of the proximal celiac artery, high-grade stenosis of the origin of the IMA, and mild to moderate stenosis of the proximal right renal artery. There was soft tissue thickening around the abdominal aorta, beginning at the origin of the SMA and extending inferiorly to near the aortic bifurcation. Minor lymphadenopathy was noted in the retroperitoneum.

CT urogram confirmed the presence of soft tissue thickening in the retroperitoneum at and just inferior to the level of the renal veins with associated lymphadenopathy. Soft tissue thickening was also present along a nonopacified segment of the proximal left ureter. ESR and CRP were elevated $(55 \mathrm{~mm} / 1 \mathrm{~h}$ and $6.2 \mathrm{mg} / \mathrm{dL}$, respectively), while immune serologies (ANCA, antinuclear antibodies, cryoglobulins) were all negative. A diagnosis of retroperitoneal fibrosis associated with GI tract vasculitis was made. Therapy was continued at prednisone dose $10 \mathrm{mg} / \mathrm{d}$.

At the last follow-up 2 years later, CT urogram was unchanged. The prednisone dose was $5 \mathrm{mg} / \mathrm{d}$. The patient was clinically asymptomatic, and creatinine was stable at $1.5 \mathrm{mg} / \mathrm{dL}$; however, the ESR remained persistently elevated $(72 \mathrm{~mm} / 1 \mathrm{~h})$.

\section{Case 3}

A 59-year-old woman was hospitalized because of abdominal pain, fever, and fatigue. Two years earlier, she had begun to experience postprandial abdominal pain and persistent diarrhea. The pain was described as a hot burning sensation relieved by avoidance of food. She also had nausea with weight loss (15 kg), mainly in the last year. An angiogram was performed with evidence of right renal artery stenosis, $95 \%$ stenosis of the origin of the celiac axis, and complete occlusion of both the SMA and IMA. CT scans of the abdomen showed aneurysmal dilatation, diffuse wall thickening, and a periaortic cuff of inflammatory soft tissue surrounding the infrarenal abdominal aorta. A diagnosis of IAAA and GI tract vasculitis with critical arterial occlusion was made, and aorta-mesenteric bypass was performed.

A few days after the intervention, the patient began again to complain of upper abdominal pain and back pain. Ultrasonography showed normal appearance of the aorto-mesenteric bypass without evidence of stenoses. CT of the abdomen and pelvis confirmed the presence of the inflammatory aneurysm of the infrarenal abdominal aorta extending to the level of the bifurcation. However, it also showed diffuse wall thickening of the GI tract from the stomach to the mid-transverse colon, consistent with ischemic changes in the distribution of the celiac artery and SMA. Upper endoscopy revealed multiple erythematous and bloody areas suggestive of ischemia scattered throughout the stomach and all portions of the duodenum.

Because of persisting abdominal pain aggravated by food intake, a mesenteric arteriogram was performed, which showed numerous smooth-tapered narrowings of multiple SMA branches and of the right hepatic and left gastric arteries. Most of these lesions were not present on the previous angiogram.

Treatment with prednisone $25 \mathrm{mg} / \mathrm{d}$ was initiated. ESR was $29 \mathrm{~mm} / 1 \mathrm{~h}$ after starting prednisone, while immunologic tests (ANCA, antinuclear, anti-DS-DNA, and anti-ENA antibodies, cryoglobulins) were all negative. The abdominal pain gradually improved. One month after the start of prednisone treatment, repeat CT of the abdomen and pelvis was performed, which showed resolution of the previously noted diffuse wall thickening of the GI tract from the stomach to the mid-transverse colon. A new angiogram was unchanged from the previous study, while a colonoscopy was negative. Two months later, the patient was much improved clinically. The postprandial pain and diarrhea had resolved, and she had gained $9 \mathrm{~kg}$ since the surgery. A CT scan of the abdomen was unchanged. The prednisone dose was tapered by $2.5 \mathrm{mg}$ every 2 weeks and was discontinued after 4 months. The patient remained clinically well until 5 years later, when she developed acute-onset abdominal pain and was found to have an occluded bypass graft. The graft was revised; however, CT of the abdomen showed near-complete infarction of the spleen and of a large part of the lateral segment of the left hepatic lobe. Moderate thickening of mid-distal small bowel loops in the lower abdomen and pelvis were also observed, consistent with ischemia. The abdominal pain improved, but subsequently recurred. A diagnosis of small bowel obstruction related to ischemic strictures was made. The patient was taken to the operating room for small bowel resection, partial resection of the left hepatic lobe, and splenectomy. She slowly improved, and 2 months later, at the last follow-up visit, was able to tolerate an unrestricted diet and had normal bowel function and had only slight abdominal pain. Her only medication was prednisone $5 \mathrm{mg} / \mathrm{d}$, which had been started 4 months previously for widespread aches and pains.

\section{Case 4}

A 49-year-old woman presented with subacute onset of dull, epigastric abdominal pain, mild nausea, and decreased appetite. Intermittent late-afternoon fever was present. ESR was $70 \mathrm{~mm} / 1 \mathrm{~h}$ and CRP was $8.7 \mathrm{mg} / \mathrm{dL}$. CT of abdomen showed a proximal abdominal aorta with diffuse wall thickening and a periaortic cuff of inflammatory soft tissue suggestive of periaortitis. A diagnosis of abdominal periaortitis was made and treatment was initiated with prednisone $20 \mathrm{mg} / \mathrm{d}$. Her abdominal pain improved significantly, and 1 month later ESR and CRP were $30 \mathrm{~mm} / 1 \mathrm{~h}$ and $3.5 \mathrm{mg} / \mathrm{dL}$, respectively. Two months later, azathioprine was started as a steroid-sparing agent with a target dose of $200 \mathrm{mg} / \mathrm{d}$. Prednisone was maintained at $10 \mathrm{mg} / \mathrm{d}$ because of persistently elevated ESR and CRP levels (around $50 \mathrm{~mm} / 1$ hour and $3.2 \mathrm{mg} / \mathrm{dL}$, respectively).

Fourteen months later, the patient's CRP level was $6 \mathrm{mg} / \mathrm{dL}$ and her abdominal pain was mild, but an abdominal CT scan showed the development of an aneurysmal enlargement of the inflamed abdominal aorta. Three months thereafter, the abdominal pain continued to be intermittent, and the patient still complained of poor appetite and had had a 7-kg weight loss over the past year.

On examination, a pulsatile mass and bruit were noted in the epigastrium. MRI/MRA showed a rapidly enlarging proximal abdominal aortic aneurysm and high-grade stenoses at the 
origins of the celiac artery and SMA with poststenotic dilatation, and stenosis of the right renal artery. Diffuse aorta wall thickening and periaortic inflammatory changes present on the first CT were improved. ESR was $110 \mathrm{~mm} / 1 \mathrm{~h}$, CRP $4.1 \mathrm{mg} / \mathrm{dL}$, and creatinine $1.3 \mathrm{mg} / \mathrm{dL}$. Immunologic tests (antinuclear, antiDS-DNA, anti-ENA antibodies, ANCA, cryoglobulins, and rheumatoid factor) were negative. A diagnosis of GI tract vasculitis was made, and the prednisone dose was increased to 40 $\mathrm{mg} / \mathrm{d}$. Two months later, ESR and CRP were elevated at $70 \mathrm{~mm} / 1$ $\mathrm{h}$ and $2.1 \mathrm{mg} / \mathrm{dL}$. Despite an occasional dull ache in the epigastrium, the patient had regained some weight.

Three months later, CT scan revealed an increase in size of the aortic aneurysm and a slight worsening of the right renal artery stenosis. Therefore, cyclophosphamide pulse therapy $1 \mathrm{~g}$ intravenously (IV) administered monthly was started, while the prednisone was maintained at $40 \mathrm{mg} / \mathrm{d}$. Two months later, a repeat CT angiogram of the abdomen showed worsening of vasculitis with occlusion and diffuse wall thickening of the celiac axis distal to the left gastric artery, occlusion at the origin of the right renal artery, and high-grade stenosis at the origin of the left renal artery. Left renal and spleen infarcts were also observed. ESR and CRP were $97 \mathrm{~mm} / 1 \mathrm{~h}$ and $12.1 \mathrm{mg} / \mathrm{dL}$, respectively. The crampy abdominal pain recurred, and the patient was treated with IV pulses of methylprednisolone $120 \mathrm{mg} / \mathrm{d}$ for 8 days. At this point, the patient underwent surgical repair of the abdominal aortic aneurysm and reconstruction of the mesenteric and renal arteries with 4 bypasses.

Three months later, tapering of the prednisone dose to $20 \mathrm{mg} / \mathrm{d}$ was initiated. ESR and CRP were $30 \mathrm{~mm} / 1 \mathrm{~h}$ and $0.4 \mathrm{mg} / \mathrm{dL}$, respectively. Six months later, while on prednisone $2.5 \mathrm{mg} / \mathrm{d}$, the patient developed malaise, fatigue, and decreased appetite. Her ESR was $99 \mathrm{~mm} / 1$ hour and CRP $4.3 \mathrm{mg} / \mathrm{dL}$. The prednisone dose was increased to $30 \mathrm{mg} / \mathrm{d}$. At the last follow-up visit 4 months later, the prednisone dose was reduced to $15 \mathrm{mg} / \mathrm{d}$ without further recurrence of symptoms.

\section{Case 5}

A 23-year-old man developed fatigue and left upper quadrant abdominal pain unrelated to food intake or activity without changes in bowel habit. Physical examination showed mild left upper tenderness with no rebound tenderness or guarding and easily palpable abdominal aortic pulse. An abdomen CT scan performed 3 weeks later showed a $4.9-\mathrm{cm}$ infrarenal abdominal aortic aneurysm with diffuse wall thickening and a surrounding periaortic inflammation, consistent with IAAA. The internal iliac arteries and the IMA were occluded. ESR was $20 \mathrm{~mm} / 1 \mathrm{~h}$; immunologic (antinuclear antibodies, ANCA, and cryoglobulins) and microbiologic (syphilis IgG and $\mathrm{IgM}$, human immunodeficiency virus [HIV], hepatitis virus $\mathrm{B}$ and $\mathrm{C}$ ) tests were negative. Genetic consultation failed to reveal any evidence of connective tissue dysplasia such as EhlersDanlos or Marfan syndromes.

A diagnosis of GI tract vasculitis associated with IAAA was made, and prednisone $60 \mathrm{mg} / \mathrm{d}$ was started with resolution of the abdominal pain. The prednisone dose was gradually reduced. Three months later, while on prednisone dose, $10 \mathrm{mg} / \mathrm{d}$, the patient underwent surgical repair of the abdominal aneurysm. Pathology of the excised aneurysm wall showed marked adventitial fibrosis and chronic inflammation with medial thinning and focal medial loss (Figure 2B). IgG4 staining showed no increase in IgG4 plasma cells.

Four months later, the prednisone was withdrawn, but soon thereafter mid-epigastric waxing and waning abdominal pain unrelated to food intake reappeared. ESR was $16 \mathrm{~mm} / 1 \mathrm{~h}$ and CRP $1.05 \mathrm{mg} / \mathrm{dL}$. One month later, intermittent fever with occasional night sweats developed. By 4 months later, CRP was found to be increased at $3.75 \mathrm{mg} / \mathrm{dL}$, while ESR was $11 \mathrm{~mm} / 1 \mathrm{~h}$. CT angiography of the chest and abdomen showed new mural thickening of the jejunal vessels, near-complete occlusion and focal aneurysmal dilatation of the SMA, and stenoses and dilatation of multiple distal SMA branches and the hepatic artery (Figures $1 \mathrm{C}$ and D). The IMA and the iliac arteries remained chronically occluded. Prednisone was restarted at the dose of $60 \mathrm{mg} / \mathrm{d}$ in addition to methotrexate $17.5 \mathrm{mg} / \mathrm{wk}$ with complete resolution of the clinical manifestations.

Two months later, when the prednisone dose was reduced to $15 \mathrm{mg} / \mathrm{d}$, the patient reported progressively increasing abdominal pain. An abdominal CT scan showed segment occlusion in the mid-SMA. The patient was then started on adalimumab $40 \mathrm{mg}$ every 2 weeks by subcutaneous injection and responded

TABLE 1. Clinical and Laboratory Findings of the 5 Patients With Chronic Periaortitis and Gastrointestinal Vasculitis

\begin{tabular}{|c|c|c|c|c|c|c|c|c|}
\hline $\begin{array}{l}\text { Patient/ } \\
\text { Age/ } \\
\text { Sex (yr) }\end{array}$ & $\begin{array}{l}\text { Type } \\
\text { of CP }\end{array}$ & $\begin{array}{l}\text { Distribution } \\
\text { of CP }\end{array}$ & $\begin{array}{c}\text { Ureteral } \\
\text { Involvement }\end{array}$ & Clinical Symptoms & $\begin{array}{l}\text { Gastrointestinal } \\
\text { Symptoms }\end{array}$ & $\begin{array}{l}\text { Time From } \\
\text { GI Symptom } \\
\text { Onset to } \\
\text { Diagnosis }\end{array}$ & $\begin{array}{l}\text { Time Between } \\
\text { CP and GI } \\
\text { Vasculitis } \\
\text { Diagnoses }\end{array}$ & $\begin{array}{l}\text { ESR* }^{*} \\
(\mathbf{m m} / \mathbf{h})\end{array}$ \\
\hline $1 / 77 / \mathrm{M}$ & PRF & $\begin{array}{l}\text { Periaortic } \\
\text { and periliac }\end{array}$ & Unilateral & $\begin{array}{l}\text { Fever, fatigue, anorexia, } \\
\text { left leg deep vein } \\
\text { thrombosis, bilateral } \\
\text { hydrocele }\end{array}$ & $\begin{array}{l}\text { Abdominal pain, } \\
\text { diarrhea, nausea, } \\
\text { weight loss } \\
\text { (13 kg in } 4 \mathrm{mo})\end{array}$ & $1 \mathrm{mo}$ & Simultaneously & 86 \\
\hline $2 / 38 / \mathrm{M}$ & IRF & Periaortic & Unilateral & $\begin{array}{l}\text { Fever, fatigue, anorexia, } \\
\text { diffuse arthromyalgia, } \\
\text { night sweats }\end{array}$ & $\begin{array}{l}\text { Abdominal pain, } \\
\text { nausea }\end{array}$ & $25 \mathrm{yr}$ & Simultaneously & 55 \\
\hline $3 / 59 / \mathrm{F}$ & IAAA & Periaortic & - & $\begin{array}{l}\text { Fever, fatigue, } \\
\text { lower back pain }\end{array}$ & $\begin{array}{l}\text { Abdominal pain, } \\
\text { abdominal angina, } \\
\text { diarrhea, nausea, weight } \\
\text { loss (15 kg in } 1 \mathrm{yr})\end{array}$ & $17 \mathrm{wk}$ & Simultaneously & - \\
\hline $4 / 49 / \mathrm{F}$ & IAAA & Periaortic & - & Fatigue, anorexia, fever & $\begin{array}{l}\text { Abdominal pain, nausea, } \\
\text { weight loss ( } 7 \mathrm{~kg} \text { in } 1 \mathrm{yr})\end{array}$ & $18 \mathrm{wk}$ & $3 \mathrm{mo}$ & 70 \\
\hline $5 / 23 / \mathrm{M}$ & IAAA & Periaortic & - & Fatigue, fever & Abdominal pain & $1 \mathrm{mo}$ & Simultaneously & 20 \\
\hline
\end{tabular}

*Before the start of therapy. 
very well. Prednisone was subsequently tapered and was completely discontinued 5 months after starting adalimumab. Approximately 10 months after starting adalimumab, methotrexate was discontinued due to abnormal liver function tests. At his last follow-up visit (31 months from diagnosis), the patient was on monotherapy with adalimumab and had been off prednisone for 6 months. At that time, he was asymptomatic and had normal ESR and CRP. CT imaging of the intraabdominal vessels showed stable findings with no disease progression.

\section{RESULTS}

\section{Demographic, Clinical Features, and Laboratory Investigations}

Of the 608 patients diagnosed at the Mayo Clinic between 1996 and 2007 with vasculitis of the GI tract, 5 patients also had CP (1 patient with PRF, 1 with IRF and 3 with IAAAs) at the time of the onset of GI manifestations.

Table 1 shows the clinical characteristics and laboratory findings of the 5 patients described in detail above. Three were men. The median age at diagnosis was 49 years. GI vasculitis and $\mathrm{CP}$ were diagnosed simultaneously in 4 patients. The time from onset of GI manifestations to diagnosis of GI vasculitis was 1 month for 2 patients; the median interval was 17 months.

All patients had abdominal pain. Four patients had nausea, 3 weight loss, 2 diarrhea, and 1 abdominal angina. Constitutional features (fatigue, anorexia, fever, diffuse arthralgia, and/or myalgia) were present in all patients, while lower extremity deep vein thrombosis, bilateral hydroceles, and night sweats occurred in 1 patient each. Unilateral hydronephrosis occurred in 1 patient, requiring a urethral stent. Patient 3 developed an acute abdomen due to small bowel obstruction caused by ischemic strictures requiring exploratory laparotomy. In this patient, upper endoscopy showed ischemic gastritis and duodenitis. Patient 1 had a colonoscopy that demonstrated ischemic colitis.

ESR before therapy was elevated in 4 of the 5 patients with available data (median value, $62.5 \mathrm{~mm} / 1 \mathrm{~h}$ ). Immunologic tests (antinuclear antibody, ANCA, cryoglobulins, anti-DSDNA, anti-ENA, and rheumatoid factor) were negative in all 5 patients.

\section{Radiology Results}

Table 2 shows the findings of conventional angiography, MRI and/or MRA, and CT and/or CT-angiography at presentation. In all patients multiple lesions were detected affecting multiple GI arteries. The most commonly involved blood vessel was the IMA (4/5), followed by the SMA (3/5). Three patients had unilateral renal artery stenosis.

At presentation, 2 patients (Patients 3 and 5) had IAAA, while Patients 1 and 4 developed aneurysmal enlargement during the follow-up. The latter 2 patients had evidence of inflammation of the infrarenal aorta at presentation. Patient 2 already had soft tissue thickening in the retroperitoneum and some degree of retroperitoneal lymphadenopathy that remained stable during the follow-up. CT evidence of spleen infarcts was present in 2 patients (Patients 3 and 4), liver infarction in 1 (Patient 3), and small and large bowel wall thickening in 1 (Patient 3 ).

\section{Pathology Results}

Pathology specimens were available for 3 patients. Patient 1 had a CT-guided biopsy of the retroperitoneal soft tissue mass that confirmed the diagnosis of IRF (Figure 2A). In Patient 3,

TABLE 2. Imaging and Pathology Findings

\begin{tabular}{|c|c|c|c|c|}
\hline Patient & Angiography & MRI/MRA & CT/CT Angiography & Pathology \\
\hline 1 & $\begin{array}{l}\text { Numerous areas of smooth } \\
\text { narrowing and dilatation } \\
\text { in multiple visceral } \\
\text { branches in the } \\
\text { SMA distribution }\end{array}$ & - & $\begin{array}{l}\text { Soft tissue thickening } \\
\text { partially surrounding the } \\
\text { thickened infrarenal abdominal } \\
\text { aorta and circumferentially } \\
\text { thickened IMA }\end{array}$ & Retroperitoneal fibrosis \\
\hline 2 & - & $\begin{array}{l}\text { Moderate/severe stenoses } \\
\text { of proximal celiac artery, } \\
\text { IMA at the origin, and } \\
\text { proximal right renal artery. } \\
\text { Soft tissue mass surrounding } \\
\text { infrarenal abdominal aorta }\end{array}$ & $\begin{array}{l}\text { CT-urogram: soft tissue } \\
\text { thickening in the } \\
\text { retroperitoneum, extending } \\
\text { along the left ureter; } \\
\text { some retroperitoneal } \\
\text { adenopathy }\end{array}$ & - \\
\hline 3 & $\begin{array}{l}95 \% \text { stenosis of the origin } \\
\text { of the celiac axis, } \\
\text { complete occlusion of both } \\
\text { SMA and IMA, and right } \\
\text { renal artery stenosis }\end{array}$ & - & $\begin{array}{l}\text { Aneurysmal dilatation and } \\
\text { diffuse wall thickening of the } \\
\text { infrarenal aorta, and periaortic } \\
\text { cuff of soft tissue inflammation }\end{array}$ & $\begin{array}{l}\text { Small bowel, liver, } \\
\text { and spleen infarcts }\end{array}$ \\
\hline 4 & - & $\begin{array}{l}\text { High-grade stenoses at the } \\
\text { origins of the celiac artery, } \\
\text { SMA (with poststenotic } \\
\text { dilatation), and right } \\
\text { renal artery }\end{array}$ & $\begin{array}{l}\text { Infrarenal abdominal aorta with } \\
\text { diffuse wall thickening and } \\
\text { periaortic cuff of soft tissue } \\
\text { inflammation }\end{array}$ & - \\
\hline 5 & - & - & $\begin{array}{l}\text { Infrarenal abdominal aortic } \\
\text { aneurysm with diffuse wall } \\
\text { thickening and periaortic cuff } \\
\text { of soft tissue inflammation, } \\
\text { occlusions of internal iliac } \\
\text { arteries, and IMA }\end{array}$ & $\begin{array}{l}\text { Abdominal aorta aneurysm } \\
\text { wall: marked adventitial } \\
\text { fibrosis, chronic inflammation } \\
\text { with medial thinning, and } \\
\text { focal medial loss; IgG4 } \\
\text { staining showed no increase } \\
\text { in IgG4 plasma cells }\end{array}$ \\
\hline
\end{tabular}


histologic examination of surgically removed abdominal samples showed small bowel infarcts and infarction of the spleen and liver. Finally, in Patient 5, histologic examination of a specimen of the abdominal aorta wall performed during aneurysm repair showed marked adventitial fibrosis and chronic inflammation (Figure 2B) with medial thinning and focal medial loss. IgG4 staining showed no increase in the amount of IgG4 plasma cells infiltrating the tissue.

\section{Treatment and Outcome}

Three patients underwent surgical intervention. Patient 3 had aorto-mesenteric bypass and resections of small bowel, part of the left liver, and spleen. Two patients (Patients 4 and 5) had repair of the abdominal aneurysm. Patient 4 also had reconstruction of mesenteric and renal arteries with 4 bypasses. A right ureteral stent was placed in Patient 1.

All 5 patients received oral prednisone. The median starting dose was $60 \mathrm{mg} / \mathrm{d}$ (range, $25-80 \mathrm{mg} / \mathrm{d}$ ). The details of treatment and status of patients at last follow-up are shown in Table 3 . In 1 patient oral prednisone therapy was preceded by pulse methylprednisolone therapy $(120 \mathrm{mg} / \mathrm{d}$ for $8 \mathrm{~d}$, Patient 4$)$. The median duration of oral prednisone therapy was 37 months (range, $11 \mathrm{mo}$ to $27 \mathrm{yr}$ ). Two patients were treated with prednisone alone, and 3 were treated with corticosteroids and immunosuppressive agents. Two patients (Patients 1 and 5) received methotrexate $(15 \mathrm{mg} / \mathrm{wk}$ for $3 \mathrm{mo}$ and $17.5 \mathrm{mg} / \mathrm{wk}$ for 12 mo, respectively), and 1 patient (Patient 4) received oral azathioprine $(200 \mathrm{mg} / \mathrm{d}$ for $22 \mathrm{mo}$ ) that was subsequently switched to monthly IV cyclophosphamide pulse therapy $(1 \mathrm{~g} / \mathrm{mo}$ for $15 \mathrm{mo}$ ) because of a relapse. Patient 1 was also treated with tamoxifen $(20 \mathrm{mg} / \mathrm{d}$ for $36 \mathrm{mo})$, and Patient 5 with the anti-tumor necrosis factor agent adalimumab.

Overall, all 5 patients had at least 1 relapse or recurrence. Response to therapy was noted in all patients, even after relapses or recurrences.

Patient 1 responded well to prednisone therapy with resolution of GI and constitutional manifestations; however, he had 2 relapses when the prednisone dose was reduced to $4 \mathrm{mg} / \mathrm{d}$ and $5 \mathrm{mg} / \mathrm{d}$, respectively. The first relapse was characterized by the appearance of bilateral hydroceles. Abdomen MRI/MRA showed worsening of retroperitoneal fibrosis, aneurysmal ectasia of the infrarenal aorta, and bilateral renal artery stenoses. Therefore, the prednisone dose was increased to $30 \mathrm{mg} / \mathrm{d}$, and tamoxifen $20 \mathrm{mg} / \mathrm{d}$ was started.

The second relapse occurred 3 years later. Right hydrocele was worse at inspection (more tense and fuller) and there was some concern that fibrosis might have worsened as assessed by CT. The prednisone dose was increased from $5 \mathrm{mg} / \mathrm{d}$ to $10 \mathrm{mg} / \mathrm{d}$, and methotrexate $15 \mathrm{mg} / \mathrm{wk}$ was substituted for tamoxifen. At last follow-up 3 months later, the patient was in remission on this same therapy.

Patient 2 had been on prednisone therapy for 27 years. During the first 25 years, the dose was $10 \mathrm{mg} / \mathrm{d}$. Attempts to taper and discontinue the corticosteroid therapy failed due to recurrences of abdominal pain. However, during the last 2 years the patient was able to gradually reduce the prednisone dose to $5 \mathrm{mg} / \mathrm{d}$ without suffering a disease relapse. At the last followup visit, CT urogram was unchanged.

Patient 3 was treated with prednisone only. Five years after stopping therapy, she had a recurrence characterized by small bowel ischemic obstruction as well as liver and spleen infarctions. Small bowel resection, resection of part of the left liver, and splenectomy were subsequently necessary. The patient responded well to surgical intervention. At last follow-up visit, 2 months later, she was in remission on prednisone $5 \mathrm{mg} / \mathrm{d}$, which had been started 4 months previously because of generalized arthralgia and/or myalgia.

Patient 4 was successfully treated at disease onset. The first relapse occurred 20 months after starting treatment, while she was taking prednisone $10 \mathrm{mg} / \mathrm{d}$. MRI/MRA showed a rapidly enlarging abdominal aneurysm and stenoses of the celiac artery, SMA, and right renal artery. The prednisone dose was increased to $40 \mathrm{mg} / \mathrm{d}$, and GI symptoms markedly improved. The second relapse occurred 5 months later, while she was still taking prednisone $40 \mathrm{mg} / \mathrm{d}$ because of persistent abdominal pain. The relapse was characterized by an increase in size of the abdominal aneurysm and worsening of the right renal artery stenosis on CT angiogram. IV cyclophosphamide pulse therapy $(1 \mathrm{~g} / \mathrm{mo})$ was started, and azathioprine discontinued, while prednisone was maintained at the dose of $40 \mathrm{mg} / \mathrm{d}$.

Two months later, the patient had the third relapse. She complained of crampy abdominal pain, and a CT angiogram revealed occlusion of the celiac artery and right renal artery, high-grade stenosis of the left renal artery, and left renal and spleen infarcts. IV methylprednisolone pulse therapy was started, and she underwent an abdominal aortic aneurysm repair and reconstruction of the mesenteric and renal arteries with 4 bypasses. The GI symptoms resolved. Nine months later, when the oral prednisone dose was reduced to $2.5 \mathrm{mg} / \mathrm{d}$, she developed constitutional symptoms and the ESR level increased to $99 \mathrm{~mm} / 1 \mathrm{~h}$. The prednisone dose was increased to $30 \mathrm{mg} / \mathrm{d}$. At patient's last follow-up visit, 4 months later, the prednisone dose was reduced to $15 \mathrm{mg} / \mathrm{d}$, and she was clinically asymptomatic.

Patient 5 was initially treated with prednisone only. However, 5 months after stopping therapy, prednisone had to be restarted at the dose of $60 \mathrm{mg} / \mathrm{d}$ with methotrexate $17.5 \mathrm{mg} / \mathrm{wk}$ because of recurrence of GI and constitutional symptoms. CT angiogram showed new mural thickening of the jejunal vessels, near-complete occlusion and focal aneurysmal dilatation of the SMA, and stenoses/dilatation of multiple distal SMA branches and the hepatic artery.

The patient responded well and symptoms resolved, and the prednisone was again gradually tapered. However, 2 months later, taking prednisone $15 \mathrm{mg} / \mathrm{d}$, abdominal pain reappeared and increased in intensity, while an abdominal angiogram showed a new vasculitic lesion in the SMA. The patient subsequently went into remission with anti-tumor necrosis factor therapy, and at the last follow-up visit he was able to discontinue prednisone.

\section{DISCUSSION}

We describe here 5 patients with vasculitis of the GI tract affecting medium-sized arteries associated with CP. GI vasculitis and $\mathrm{CP}$ were diagnosed concomitantly in 4 patients, suggesting that a common vasculitic process was involved in the pathogenesis of both conditions. This hypothesis is further supported by the simultaneous worsening of mesenteric vasculitis and/or renal artery stenoses and CP observed in most of the relapses. Still, the link between GIvasculitis and CP remains largely a matter of debate.

$\mathrm{CP}$ was originally interpreted as an exuberant local inflammatory reaction to atherosclerotic plaques in the abdominal aorta. ${ }^{35-37}$ However, the presence of constitutional manifestations, elevated inflammatory markers, and, sometimes, of various autoantibodies in CP patients reported in subsequent studies appears to point away from a localized and toward a systemic inflammatory process. ${ }^{43-45}$ Consistent with this hypothesis, a recent study demonstrated that all patients with $\mathrm{CP}$ had evidence on FDG-PET of grade 2+ or 3+ vascular uptake in the abdominal aorta and/or iliac artery, consistent with widespread large-vessel 


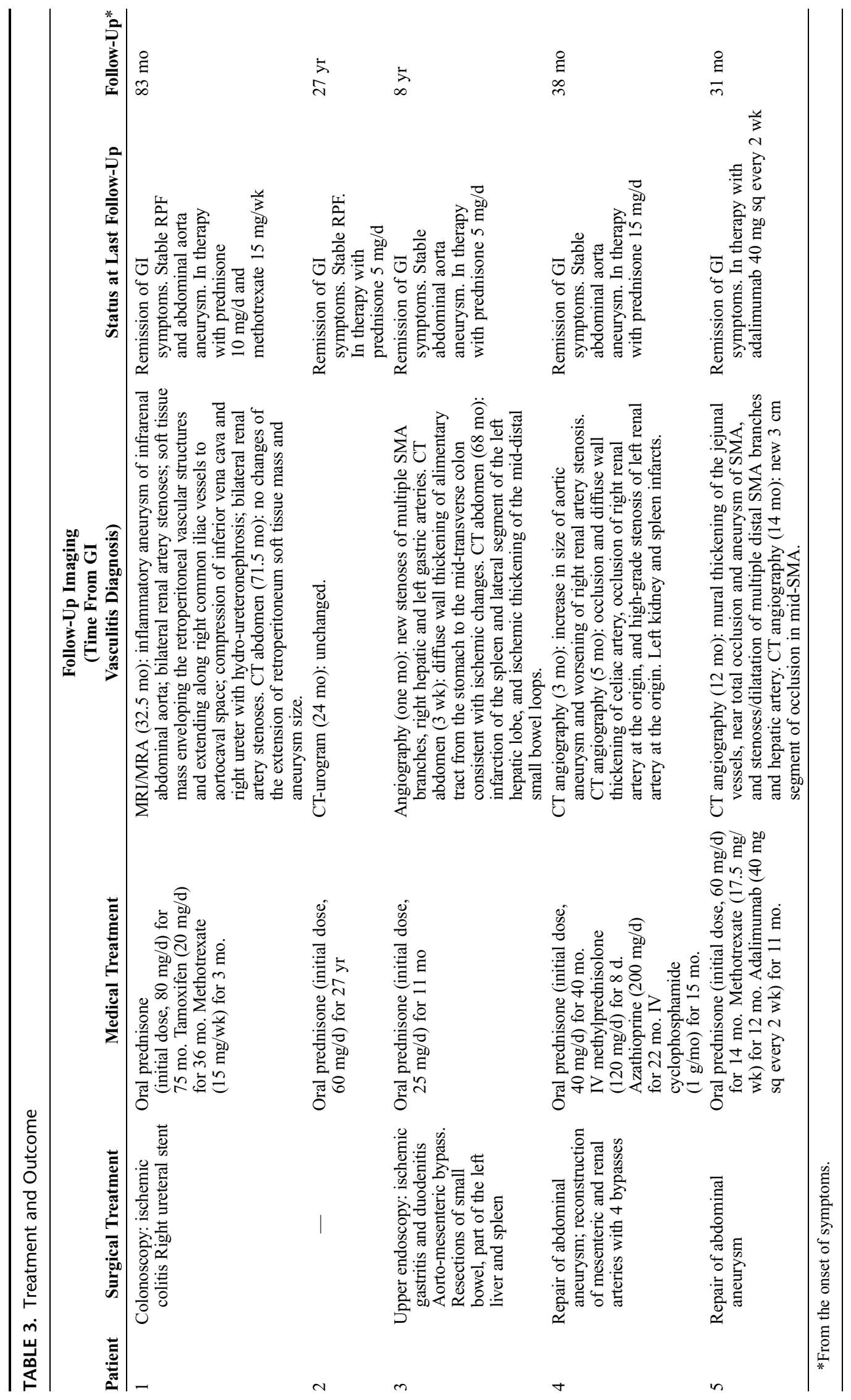


TABLE 4. Association Between Chronic Periaortitis and Vasculitides Reported in Literature

\begin{tabular}{|c|c|c|c|}
\hline $\begin{array}{l}\text { First Author Year } \\
\text { (Reference) }\end{array}$ & $\begin{array}{c}\text { No. of } \\
\text { Patients }\end{array}$ & Retroperitoneal Findings & Vasculitides \\
\hline \multicolumn{4}{|l|}{ Large vessel } \\
\hline Kuwana 1992 (21) & 1 & $\begin{array}{l}\text { Bilateral ureteral obstruction with bilateral hydronephrosis } \\
\text { CT: periaortic retroperitoneal mass and thickening } \\
\text { of the aortic wall }\end{array}$ & $\begin{array}{l}\text { Stenosis/dilatation of aortic } \\
\text { arch, left renal artery, } \\
\text { and splenic artery }\end{array}$ \\
\hline Le Moal 2001 (23) & 1 & CT: thoracic-abdominal periaortitis & $\begin{array}{l}\text { Biopsy-negative large-vessel } \\
\text { giant cell arteritis }\end{array}$ \\
\hline Salvarani 2005 (40) & 3 & $\begin{array}{l}\text { Left ureteral obstruction with hydroneophrosis in } 1 \text { case } \\
\text { CT and FDG-PET: perivascular soft tissue mass involving } \\
\text { the abdominal aorta and iliac arteries in all } 3 \text { patients, } \\
\text { inflammatory abdominal aneurysm in } 1 \text { patient }\end{array}$ & $\begin{array}{l}\text { Involvement of thoracic aorta } \\
\text { and/or its branches } \\
\text { (vascular uptake on FDG-PET) }\end{array}$ \\
\hline Vaglio 2008 (47) & 14 & $\begin{array}{l}\text { CT, MRI, FDG-PET: perivascular soft tissue mass } \\
\text { involving the abdominal aorta and iliac arteries }\end{array}$ & $\begin{array}{l}\text { Involvement of the thoracic aorta } \\
\text { and its branches ( } 9 \text { patients } \\
\text { had thoracic periaortitis, } \\
2 \text { thoracic periaortitis and } \\
\text { pericarotid involvement, } \\
3 \text { thoracic aneurysm) }\end{array}$ \\
\hline \multicolumn{4}{|l|}{ Medium vessel } \\
\hline Hellstrom 1966 (14) & 1 & $\begin{array}{l}\text { Bilateral ureteral obstruction with hydronephrosis } \\
\text { Pathology: fibro-inflammatory tissue showing } \\
\text { necrotizing vasculitis }\end{array}$ & $\begin{array}{l}\text { Necrotizing vasculitis involving } \\
\text { small arteries of gallbladder, } \\
\text { liver, and testes }\end{array}$ \\
\hline Carton 1969 (7) & 1 & $\begin{array}{l}\text { Biopsies during bilateral lumbar sympathectomy: } \\
\text { necrotizing vasculitis of the medium-sized arteries } \\
\text { accompanying the sympathetic chain } \\
\text { Autopsy: mediastinal and retroperitoneal fibrosis }\end{array}$ & Polyarteritis nodosa (probable) \\
\hline Métahni 1988 (28) & 1 & $\begin{array}{l}\text { Bilateral ureteral obstruction with hydronephrosis } \\
\text { CT: retroperitoneal perianeurysmal mass } \\
\text { Surgical intervention for abdominal aneurysm }\end{array}$ & Polyarteritis nodosa \\
\hline Bourgault 1989 (5) & 1 & $\begin{array}{l}\text { Left ureteral obstruction with hydronephrosis } \\
\text { CT: retroperitoneal mass } \\
\text { Pathology: fibrotic tissue }\end{array}$ & Polyarteritis nodosa \\
\hline Hautekeete 1990 (12) & 1 & $\begin{array}{l}\text { Bilateral ureteral obstruction with hydronephrosis } \\
\text { CT: soft tissue mass around the aortic } \\
\text { prosthesis, reaching forward toward the mesentery }\end{array}$ & Polyarteritis nodosa \\
\hline Iino $1992(17)$ & 1 & $\begin{array}{l}\text { Pathology: aortic dissection with necrotizing vasculitis } \\
\text { in the vasa vasorum of the adventitia and media } \\
\text { of the thoracic aorta }\end{array}$ & Polyarteritis nodosa \\
\hline van Bommel 2002 (48) & 1 & $\begin{array}{l}\text { CT: retroperitoneal mass surrounding the } \\
\text { inferior cava vein and abdominal aorta }\end{array}$ & Polyarteritis nodosa \\
\hline \multicolumn{4}{|l|}{ Small vessel } \\
\hline Baker 1978 (3) & 1 & $\begin{array}{l}\text { Left ureteral obstruction with hydronephrosis } \\
\text { Pathology: fibro-inflammatory tissue with necrotizing } \\
\text { vasculitis involving small and medium-sized arteries }\end{array}$ & Wegener granulomatosis \\
\hline Hollingworth 1980 (15) & 1 & $\begin{array}{l}\text { Bilateral ureteral obstruction with hydronephrosis } \\
\text { Inferior venocavagram: blockage } \\
\text { at the same level as ureteral blockage } \\
\text { CT: no mass in the region corresponding to } \\
\text { inferior cava venal and ureteral obstruction }\end{array}$ & Wegener granulomatosis \\
\hline Metselaar 1985 (29) & 1 & $\begin{array}{l}\text { Left ureteral obstruction with hydronephrosis Pathology: } \\
\text { fibro-inflammatory tissue showing necrotizing vasculitis }\end{array}$ & Wegener granulomatosis \\
\hline Leche 1985 (22) & 1 & $\begin{array}{l}\text { Bilateral ureteral obstruction with acute renal failure } \\
\text { Pathology: inflammatory tissue with vasculitis }\end{array}$ & Wegener granulomatosis \\
\hline Adelizzi 1986 (1) & 1 & $\begin{array}{l}\text { Bilateral ureteral obstruction with right hydronephrosis } \\
\text { Pathology: inflammatory tissue with prevalent lymphocytes, } \\
\text { granulomas, and numerous scattered eosinophils }\end{array}$ & Wegener granulomatosis \\
\hline Sieber $1990(41)$ & 1 & $\begin{array}{l}\text { CT and aortogram: left lateral periaortic mass near the } \\
\text { aortic bifurcation } \\
\text { Exploratory laparotomy: inflammatory aortic aneurysm } \\
\text { extending from the renal arteries to the aortic bifurcation } \\
\text { Aneurysmal wall biopsy specimen: granulomatous } \\
\text { inflammatory process }\end{array}$ & Wegener granulomatosis \\
\hline
\end{tabular}




\begin{tabular}{|c|c|c|c|}
\hline $\begin{array}{l}\text { First Author Year } \\
\text { (Reference) }\end{array}$ & $\begin{array}{c}\text { No. of } \\
\text { Patients }\end{array}$ & Retroperitoneal Findings & Vasculitides \\
\hline ter Maaten 1993 (42) & 1 & $\begin{array}{l}\text { Left ureteral obstruction } \\
\text { Pathology: necrotizing granulomatous vasculitis }\end{array}$ & Wegener granulomatosis \\
\hline Middleton 1994 (30) & 1 & $\begin{array}{l}\text { Right ureteral obstruction with hydronephrosis } \\
\text { CT: soft tissue retroperitoneal mass extending } \\
\text { bilaterally along the course of the ureters from } \\
\text { just below the kidney to the common iliac arteries }\end{array}$ & Wegener granulomatosis \\
\hline Fink 1994 (10) & 1 & $\begin{array}{l}\text { Right ureteral obstruction with hydronephrosis } \\
\text { CT: thickened ill-defined tissue around the aorta, } \\
\text { extending to the right iliac artery } \\
\text { Pathology: extensive active vasculitis }\end{array}$ & Wegener granulomatosis \\
\hline Blockmans 2000 (4) & 1 & $\begin{array}{l}\text { CT: dilatation of the distal part of } \\
\text { abdominal aorta, thickened aortic wall, } \\
\text { a patent excentric lumen surrounded by a hypodense rim } \\
\text { Pathology: inflammatory tissue with necrotizing } \\
\text { granulomatous vasculitis }\end{array}$ & Wegener granulomatosis \\
\hline Izzedine $2002(18)$ & 1 & $\begin{array}{l}\text { Left ureteral obstruction with hydronephrosis } \\
\text { Pathology: fibro-inflammatory tissue }\end{array}$ & Wegener granulomatosis \\
\hline de Roux-Serratrice 2002 (9) & 1 & $\begin{array}{l}\text { CT: ectasia of infrarenal aorta and periaortic } \\
\text { inflammatory infiltration }\end{array}$ & Wegener granulomatosis \\
\hline Carels 2005 (6) & 1 & $\begin{array}{l}\text { CT: } 4 \text {-cm aneurysm of the distal part of the aorta } \\
\text { with inflammation of the surrounding adipose tissue } \\
\text { Pathology: fibro-inflammatory tissue with vasculitis } \\
\text { and necrosis }\end{array}$ & Wegener granulomatosis \\
\hline Levin 2006 (24) & 1 & CT, CTA, FDG-PET: periaortic soft tissue mass & Wegener granulomatosis \\
\hline Akman 1983 (2) & 1 & $\begin{array}{l}\text { Bilateral ureteral obstruction with hydronephrosis } \\
\text { Pathology: fibrous tissue }\end{array}$ & Henoch-Schönlein purpura \\
\hline Vaglio 2002 (46) & 2 & $\begin{array}{l}\text { 1st case: Left ureteral obstruction with hydronephrosis } \\
\text { CT: periaortic mantle of soft tissue density } \\
\text { surrounding the left ureter } \\
\text { 2nd case: Right ureteral obstruction with hydronephrosis } \\
\text { CT and US: aneurysmal dilatation of the abdominal aorta } \\
\text { and perianeurysmal mantle of soft tissue density } \\
\text { surrounding the right ureter }\end{array}$ & $\begin{array}{l}\text { ANCA-positive rapidly } \\
\text { progressive GMN }\end{array}$ \\
\hline Martinez-Odriozola 2008 (27) & 1 & $\begin{array}{l}\text { Bilateral ureteral obstruction with ureterohydronephrosis } \\
\text { CT: retroperitoneal soft-tissue mass surrounding } \\
\text { the aorta and extending longitudinally from renal } \\
\text { arteries to common iliac arteries } \\
\text { Pathology: fibrosis and a chronic inflammatory infiltrate }\end{array}$ & $\begin{array}{l}\text { ANCA-positive rapidly } \\
\text { progressive GMN }\end{array}$ \\
\hline
\end{tabular}

Abbreviations: $\mathrm{CTA}=$ computed tomography angiography, $\mathrm{US}=$ ultrasonography, $\mathrm{GMN}=$ glomerulonephritis.

vasculitis involving these arteries. ${ }^{40}$ Vasculitis of the thoracic aorta and/or its branches was documented by FDG-PET, CT angiography, and MRA in $34 \%$ of 41 consecutive Italian CP patients, ${ }^{47}$ while reports of aortic arch syndrome in CP appear to confirm that CP may also affect the thoracic aorta ${ }^{21,23}$ (Table 4). Along the same lines, autopsy studies have shown that the adventitial inflammation and fibrosis seen in CP may not be limited to the abdominal aorta, but may also involve the thoracic portion. $^{19,32}$

Histologic evaluation of these cases has failed to reveal significant differences between IAAA and IRF apart from an increase in aortic diameter in the former. ${ }^{35}$ In IAAAs, histopathologic findings demonstrate that most of the thickening of the aortic wall is due to an enlargement of the adventitia caused by a marked inflammatory reaction. ${ }^{35,49}$ The inflammatory infiltrate of the aortic adventitia may have a diffuse or follicular pattern. The nodular aggregates of inflammatory cells (mainly lymphocytes) are usually centered around the adventitial vasa vasorum, which show evidence of vasculitis with fibrinoid necrosis. ${ }^{8,26,31,44}$ This inflammatory histopathologic pattern has been found in all $3 \mathrm{CP}$ subsets. These findings are in keeping with a local immune response to an antigen probably localized in the adventitia.

Taken together, imaging and histologic evidence suggest that CP may represent a large-vessel vasculitis involving the abdominal aorta and common iliac arteries, which in some patients may spread to the thoracic aorta and/or its branches. This vasculitis may be triggered by a yet-unknown inciting antigen in the adventitia.

In addition to large-vessel involvement, there is emerging evidence that medium- and small-sized arteries may also be affected in $\mathrm{CP}^{8,44}$ Vaglio et $\mathrm{al}^{44}$ found vasculitis with fibrinoid necrosis involving small- and medium-sized retroperitoneal vessels in most of the IRF patients undergoing surgery. Similarly, the cases in the current study provide evidence that medium-sized vessels located outside the retroperitoneum may be affected, albeit infrequently, in CP. Various case reports $1-7,9,10,12,14,15,17,18,22,24,27-30,41,42,46,48$ have described the involvement of medium- and small-sized vessels as part of established vasculitides, particularly granulomatous, ANCArelated necrotizing vasculitis and polyarteritis nodosa, in association with CP (see Table 4). 
These observations suggest a link between $\mathrm{CP}$ and vasculitides of small- and medium-sized vessels. Specifically, most reported patients with vasculitis and $\mathrm{CP}$ presented with ureteral obstruction and hydronephrosis (Table 4). Ureteral involvement has been described as an extrarenal urogenital manifestation of ANCA-related necrotizing granulomatous vasculitis and polyarteritis nodosa. ${ }^{16}$ Vasculitis may be the cause of ureteral obstruction because of the direct vasculitic involvement of the ureteral wall. ${ }^{13,38}$ Entrapment and obstruction of the ureters by retroperitoneal fibrosis occurred in the patients with vasculitides of small- and medium-sized vessels reported in Table 4. These findings suggest that ureteral involvement occurring in vasculitides such as ANCA-related necrotizing granulomatous vasculitis and polyarteritis nodosa may be secondary not only to vasculitis, but also to vasculitis-associated CP.

In addition to being associated with vasculitis, $\mathrm{CP}$ may also arise in the context of the so-called IgG4-related sclerosing disease, a condition characterized by extensive T-lymphocyteand IgG4-bearing plasma cell infiltration of various organs leading to fibrosis. ${ }^{34}$ On the other hand, IgG4-related retroperitoneal fibrosis may develop in patients without evidence of sclerosing disease elsewhere. ${ }^{50}$ In 2008 , Kasashima et $\mathrm{al}^{20}$ described a subgroup of IAAAs showing diffuse infiltration of IgG-4 positive plasma cells and high serum IgG4 concentrations. Based on these findings, the authors suggested that this form of IAAA might be a subset of IgG4-related sclerosing disease. However, the same authors observed that most cases of IAAA were non-IgG4-related, having only a few IgG4-positive plasma cells in the aneurysm wall. In 1 patient in the current study, a surgically resected specimen of the abdominal aorta was available. The aneurysm wall exhibited marked adventitial fibrosis and chronic inflammation; however, IgG4 staining showed no increase in the amount of IgG4 plasma cells infiltrating the tissue. The role of IgG4 in the pathogenesis of IgG4-related sclerosing disease remains unclear, but the limited evidence available so far suggests that IgG4 infiltration might play a role in only a minority of all AAA/CP cases.

GI involvement due to mesenteric vasculitis is common in polyarteritis nodosa and may be associated with a poor outcome, particularly in patients who develop an acute abdomen syndrome. $^{25}$ In fact, peritonitis, bowel perforation, GI ischemia or infarction, and intestinal occlusion have been found to be significantly associated with increased mortality in a cohort of patients with GI manifestations and systemic necrotizing vasculitides. ${ }^{33}$ Two patients in the current study underwent surgery for GI manifestations. One patient had severe mesenteric vasculitis with complete occlusion of both mesenteric arteries and severe obstruction of celiac artery at its origin. Despite aortomesenteric bypass and corticosteroid therapy, she developed spleen and liver infarctions as well as small bowel obstruction due to ischemic strictures, which required small bowel resection and partial liver resection and splenectomy. The second patient had repair surgery of the mesenteric and renal arteries with 4 bypasses for complete occlusion of the celiac and right renal arteries and severe stenoses of superior mesenteric and left renal arteries. Left renal and spleen infarcts were also present.

These observations suggest that mesenteric vasculitis associated with CP is probably as severe as that seen in other established vasculitides. Therefore, it is critical that physicians endeavor to recognize this condition promptly, because early, aggressive immunosuppressive treatment may prevent abdominal complications.

GI manifestations were successfully treated in most of our patients with corticosteroid therapy, which was combined with immunosuppressive chemotherapeutic agents in 3 patients and with anti-tumor necrosis factor agent in 1. At last visit, GI vasculitis and $\mathrm{CP}$ were in remission in all 5 patients. In most cases, relapses and recurrences were associated with tapering of corticosteroid therapy. Patients usually responded promptly to an increase in the dose or reintroduction of corticosteroids, sometimes associated with immunosuppressive agents. One relapse responded to the introduction of anti-tumor necrosis factor therapy. Our experience supports the use of corticosteroid treatment in $\mathrm{CP}$, which usually results in the resolution of symptoms and regression of the retroperitoneal mass. ${ }^{43}$

In conclusion, the results of the current study suggest that GI medium-sized vasculitis occurs in the context of CP. Awareness of this uncommon but potentially serious manifestation may aid the clinician in recognizing it and thus starting aggressive treatment early, which may prevent severe complications.

\section{REFERENCES}

1. Adelizzi RA, Shockley FK, Pietras JR. Wegener's granulomatosis with ureteric obstruction. J Rheumatol. 1986;13:448-451.

2. Akman N, Avanoglu Y, Karabay K, Erek E, Tokgoz A, Aras E, et al. Henoch-Schonlein purpura and retroperitoneal fibrosis. Acta Haematol. 1983;70:400-401.

3. Baker SB, Robinson DR. Unusual renal manifestations of Wegener's granulomatosis. Report of two cases. Am J Med. 1978;64:883-889.

4. Blockmans D, Baeyens H, Van Loon R, Lauwers G, Bobbaers H. Periaortitis and aortic dissection due to Wegener's granulomatosis. Clin Rheumatol. 2000;19:161-164.

5. Bourgault I, Poli F, Roujeau JC, Shaeffer A, Rodier JM, Revuz J. Retroperitoneal and mediastinal fibrosis complicating periarteritis nodosa. Ann Dermatol Venereol. 1989;116:824-825.

6. Carels T, Verbeken E, Blockmans D. p-ANCA-associated periaortitis with histological proof of Wegener's granulomatosis: case report. Clin Rheumatol. 2005;24:83-86.

7. Carton RW, Wong R. Multifocal fibrosclerosis manifested by vena caval obstructions and associated with vasculitis. Ann Intern Med. 1969;70:81-86

8. Corradi D, Maestri R, Palmisano A, Bosio S, Greco P, Manenti L, et al. Idiopathic retroperitoneal fibrosis: clinicopathologic features and differential diagnosis. Kidney Int. 2007;72:742-753.

9. de Roux-Serratrice C, Serratrice J, Granel B, Disdier P, Bartoli J-M, Pache X, et al. Periaortitis heralding Wegener's granulomatosis. $J$ Rheumatol. 2002;29:392-394.

10. Fink AM, Miles KA, Wraight EP. Indium-11 labelled leukocyte uptake in aortitis. Clin Radiol. 1994;49:863-866.

11. Gilkeson GS, Allen NB. Retroperitoneal fibrosis. A true connective tissue disease. Rheum Dis Clin North Am. 1996;22:23-38.

12. Hautekeete ML, Babany G, Marcellin P, et al. Retroperitoneal fibrosis after surgery for aortic aneurysm in a patient with periarteritis nodosa: successful treatment with corticosteroids. J Intern Med. 1990;228:53-56

13. Hefty TR, Bonafede P, Stenzel P. Bilateral ureteral stricture from polyarteritis nodosa. J Urol. 1989;141:600-601.

14. Hellstrom HR, Perezstable EC. Retroperitoneal fibrosis with disseminated vasculitis and intrahepatic sclerosing cholangitis. Am J Med. 1966;40:184-187.

15. Hollingworth P, Denman AM, Gumpel JM. Retroperitoneal fibrosis and polyarteritis nodosa successfully treated by intensive immunosuppression. J R Soc Med. 1980;73:61-64.

16. Huong DL, Papo T, Piette JC, Wechsler B, Bletry O, Richard F, Valcke JC, Godeau P. Urogenital manifestations of Wegener granulomatosis. Medicine (Baltimore). 1995;74:152-161. 
17. Iino T, Eguchi K, Sakai M, Nagataki S, Ishijima M, Toriyama K. Polyarteritis nodosa with aortic dissection: necrotizing vasculitis of the vasa vasorum. J Rheumatol. 1992;19:1632-1636.

18. Izzedine H, Servais A, Launay-Vacher V, Deray G. Retroperitoneal fibrosis due to Wegener's granulomatosis: a misdiagnosis as tuberculosis. Am J Med. 2002;113:164-166.

19. Jones EA, Alexander MK. Idiopathic retroperitoneal fibrosis associated with an arteritis. Ann Rheum Dis. 1966;25:356-360.

20. Kasashima S, Zen Y, Kawashima A, Konishi K, Sasaki H, Endo M, et al. Inflammatory abdominal aortic aneurysm: close relationship to IgG4-related periaortitis. Am J Surg Pathol. 2008;32:197-204.

21. Kuwana M, Wakino S, Yoshida T, Homma M. Retroperitoneal fibrosis associated with aortitis. Arthritis Rheum. 1992;35:1245-1247.

22. Leche J, Feuilhade C, Ferroir JP, et al. Wegener's disease of urologic and neurologic onset in French. Ann Med Interne (Paris). 1985;136:353.

23. Le Moal G, Paccalin M, Roy-Peaud F, Roblot P, Becq-Giraudon B. Horton disease manifesting as periaortitis. Rev Med Interne. 2001;22: 487-488

24. Levin A, Kasem S, Mader R, Naparstek Y, Friedman G, Ben-Yehuda A. Wegener granulomatosis with back pain, periaortitis, and dural inflammation developing while receiving monthly cyclophosphamide. J Clin Rheumatol. 2006;12:294-297.

25. Levine SM, Hellmann DB, Stone JH. Gastrointestinal involvement in polyarteritis nodosa (1986-2000): presentation and outcomes in 24 patients. Am J Med. 2002;112:386-391.

26. Lindell OL, Sariola HV, Lehtonen TA. The occurrence of vasculitis in perianeurysmal fibrosis. J Urol. 1987;138:727-729.

27. Martinez-Odriozola P, Gutierrez-Macias A, Moina Eguren L, Arrieta Lezama J. Association of idiopathic retroperitoneal fibrosis, rapidly progressive glomerulonephritis and antiproteinase 3 antineutrophil cytoplasmic antibodies (anti PR3-ANCA). Clin Nephrol. 2008;70:251-254.

28. Methani K, Vital Durand D, Sibille M, Sabben F, Levrat. Abdominal aortic aneurysm, retroperitoneal fibrosis and vasculitis. Rev Med Interne. 1988;9:188-190.

29. Metselaar HJ, ten Kate FJ, Weimar W. Ureter obstruction as a complication of Wegener's granulomatosis. Eur Urol. 1985;11: 63-64.

30. Middleton G, Karp D, Lee E, Cush J. Wegener's granulomatosis presenting as lower back pain with prostatitis and ureteral obstruction. J Rheumatol. 1994;21:566-569.

31. Mitchinson MJ. The pathology of idiopathic retroperitoneal fibrosis. J Clin Pathol. 1970;23:681-689.

32. Mitchinson MJ. Aortic diseases in idiopathic retroperitoneal and mediastinal fibrosis. J Clin Pathol. 1972;25:287-293.

33. Pagnoux C, Mahr A, Cohen P, Guillevin L. Presentation and outcome of gastrointestinal involvement in systemic necrotizing vasculitides: analysis of 62 patients with polyarteritis nodosa, microscopic polyangiitis, Wegener granulomatosis, Churg-Strauss syndrome, or rheumatoid arthritis vasculitis. Medicine (Baltimore). 2005;84: 115-128.

34. Palmisano A, Vaglio A. Chronic periaortitis: a fibro-inflammatory disorder. Best Pract Res Clin Rheumatol. 2009;23:339-353.

35. Parums DV. The spectrum of chronic periaortitis. Histopathology. 1990;16:423-431.

36. Parums DV, Chadwick DR, Mitchinson MJ. The localisation of immunoglobulin in chronic periaortitis. Atherosclerosis. 1986;61: 117-123.

37. Ramshaw AL, Parums DV. The distribution of adhesion molecules in chronic periaortitis. Histopathology. 1994;24:23-32.

38. Ronco P, Mignon F, Lanoe Y, Roland J, Moret-Maroyer L, Gattegno B. Ureteral stenosis in Wegener's granulomatosis. Report of a case. Nephron. 1982;30:201-204.

39. Salvarani C, Calamia KT, Crowson CS, Miller DV, Broadwell AW, Hunder GG, Matteson EL, Warrington KJ. Localized vasculitis of the gastrointestinal tract: a case series. Rheumatology (Oxford). 2010;49:1326-1335.

40. Salvarani C, Pipitone N, Versari A, Vaglio A, Serafini D, Bajocchi GL, et al. Positron emission tomography (PET): evaluation of chronic periaortitis. Arthritis Rheum. 2005;53:298-303.

41. Sieber SC, Cuello B, Gelfman NA, Garfinkel HB. Pulmonary capillaritis and glomerulonephritis in an antineutrophil cytoplasmic antibody-positive patient with prior granulomatous aortitis. Arch Pathol Lab Med. 1990;114:1223-1226.

42. ter Maaten JC, Franssen CFM, Daenekindt AA, Hoorntje SJ. Triple Wegener's granulomatosis in the urogenital tract. Nephron. 1993;63:358-359.

43. Vaglio A, Salvarani C, Buzio C. Retroperitoneal fibrosis. Lancet. 2006;367:241-251.

44. Vaglio A, Corradi D, Manenti L, Ferretti S, Garini G, Buzio C. Evidence of autoimmunity in chronic periaortitis: a prospective study. Am J Med. 2003;114:454-462.

45. Vaglio A, Palmisano A, Corradi D, Salvarani C, Buzio C. Retroperitoneal fibrosis: evolving concepts. Rheum Dis Clin N Am. 2007;33:803-817.

46. Vaglio A, Manenti L, Allegri L, Ferrozzi F, Corradi D, Buzio C. ANCA-positive periaortic vasculitis: does it fall within the spectrum of vasculitis? J Intern Med. 2002;251:268-271.

47. Vaglio A, Palmisano A, Buzio C, Versari A, Pipitone N, Boiardi L, Salvarani C. Large-vessel vasculitis pattern in patients with chronic periaortitis. Arthritis Rheum. 2008;58(Suppl):S400.

48. van Bommel E, Brouwers A, Makkus A, van Vliet A. Retroperitoneal fibrosis and p-ANCA-associated polyarteritis nodosa: coincidental or common etiology? Eur J Intern Med. 2002;13:392.

49. Walker DI, Bloor K, Williams G, Gillie I. Inflammatory aneurysms of the abdominal aorta. Br J Surg. 1972;59:609-614.

50. Zen Y, Onodera M, Inoue D, Kitao A, Matsui O, Nohara T, et al. Retroperitoneal fibrosis: a clinicopathologic study with respect to immunoglobulin G4. Am J Surg Pathol. 2009;33:1833-1839. 